Agrovoc descriptors: organic agriculture; alternative agriculture; traditional uses; surveys; farm surveys; sustainability; human behaviour; value systems; motivation; environmental protection; technological changes

Agris category code: F08, E20, E51

COBISS code 1.01

\title{
The characteristics of conventional and organic farmers in Podravska region ${ }^{1}$
}

\author{
Andrej UDOVČ ${ }^{2}$, Anton PERPAR ${ }^{3}$
}

Received: September 9, 2006; accepted: June 20, 2007.

Prispelo: 9. september, 2006; sprejeto: 20. junij, 2007.

\begin{abstract}
The paper presents the results of a questionnaire survey on adoption of organic farming in Podravska region. The survey was conducted on the sample of 58 organic farms and 99 conventional farms in the year 2005. The results show certain differences among both groups of farms in information adoption and attitudes towards nature sustainability. Both groups of farms use different information sources, and are members in different associations. Also the level of environmental awareness is higher by organic farmers but in many other characteristics the differences are not significant. The analysis of future plans of conventional farmers also revealed a significant proportion of farms which are undecided regarding the conversion of their farms to organic agriculture in the next 10 years.
\end{abstract}

Key words: attitudes, ecological agriculture, agri-environmental schemes

IZVLEČEK

\section{ZNAČILNOSTI KONVENCIONALNIH IN EKOLOŠKIH KMETOV V PODRAVJU}

Prispevek podaja rezultate anketne raziskave o sprejemanju ekološkega kmetijstva $v$ Podravju. Raziskava je zajela vzorec 58 ekoloških in 99 konvencionalnih kmetij v letu 2005. Rezultati kažejo določene razlike med obema preučevanima skupinama kmetij glede iskanja in uporabe informacij, in odnosa do trajnosti naravnega okolja. Tako kmetje iz posamezne skupine uporabljajo različne informacijske vire in so člani različnih združenj. Tudi raven okoljske zavesti je višja pri ekoloških kmetih, pri mnogih ostalih značinostih pa ni bilo opaziti signifikantnih razlik. Analiza prihodnjih načrtov konvencionalnih kmetov je razkrila, da je velik delež takih, ki so neopredeljeni glede možnosti konverzije svoje kmetije $v$ ekološko $v$ prihodnjih 10 letih.

Ključne besede: vedenje, ekološko kmetijstvo, kmetijsko okoljski ukrepi

1 This research was financed under the EC's FP5, Quality of Life and the Management of Living Resources (QLK5-CT-2002-02718),

2 Assist. prof., Ph.D., University of Ljubljana, Biotechnical Faculty, SI-Ljubljana, Jamnikarjeva 101, andrej.udovc@bf.uni-lj.si

3 Assist., M.Sc. ibid, anton.perpar@bf.uni-lj.si 


\section{INTRODUCTION}

Organic farming presents a possibility for part of Slovene's farms to continue with their activity and to gain a satisfactory farm income when combined together with payments from agricultural policy measures. Slovenia plans to still increase the number of organic farms and their production areas (Strategija razvoja..., 2006). The series of surveys in 2003 and 2004 (Jelen, 2003; Kejžar, 2003; Serjun, 2005; Stropnik, 2003) also found out that demand for Slovene organic products is still exceeding the existing supply of all kind of organic products in all regions. The above summarises the reasons why it is important to study the adoption and the key factors influencing the decision about starting organic farming.

In Slovenia the organic farming started to receive agricultural policy support already in the year 1999. In 2001 the Slovene agri-environment programme (SAEP) was implemented and organic farmers were legitimate to direct payments for the measures from this programme. The first payments within the SEAP were paid out in 2002. Following this, the numbers of organic producers has increased every year. For illustration, 41 organic producers applied for subsidies in 1999, as in 2004 there were already 1,489, what represents $2 \%$ of all Slovenian farms (Škerbot, Uranjek, 2005).

Our main research objectives were to analyse the agricultural situation on selected agricultural holdings (conventional and organic) in the selected region (the northeastern part of Slovenia, the Podravska region) and to compare the results between organic farmers and conventional farmers. More specifically, our study tried to find answers to the following research questions:

- Are there significant differences between organic farmers and conventional farmers regarding the agricultural situation on holdings (farm size, education level, income level, number of family members, memberships of professional associations etc.)?

- Are the relations and views to nature, concerns about future generations, environment...significant different between organic farmers and conventional farmers?

The analyses of factors that influence farmers' adoption of innovations, as well as analyses of the differences between organic and conventional farming have started in late 90ies when the participation of farmers in the EU member states in agrienvironmental programmes became more widespread. In one of the earlier analyses Wilson (1997) grouped factors influencing the adoption of certain agri-environmental scheme in "scheme factors" (e.g. payments) and "farmer factors" (e.g. age of farmer). In his analysis he proved that the strongest factor influencing the decision for adopting a certain scheme/s is farm size, where the medium size farms were most interested to adopt. That the farm size is one of the most important factors also indicated the analysis of Diederen et al (2003), Chaves (2001). On the other hand Burton in his analysis (2003) found farm size as insignificant factor. Other factors which also showed some influence on adoption of either organic farming or certain agri-environmental schemes are: education, farmer's attitude towards environment, sources of information and income situation of the farm (Wilson, 1997, Diederon, 2002, Burton 1999 and 2003, McCann and Sullivan, 1997). 


\section{METHODS}

The study sample was selected from farms in the northern part of Podravska region, where both organic and conventional farms exist side by side. The reason for selecting particular local municipalities for farm sampling was determined by the fact that the agricultural advisory service for both types of farms is offered by the same institution - the Maribor Agricultural Institute.

The sampling of organic farms was done on the basis of the membership list of the Association of Organic Farmers of Podravje, which provided us with the list of 78 farms (including farms in conversion). From this list all farms which exceeded the threshold of subsistence farms $\left(1 \mathrm{ESU}^{4}\right)$ were selected. So we got a list of 72 farms, from which 6 had already stopped to farm. Finally 59 agreed to be interviewed.

For conventional farms, a stratified sample by ESU size classes was provided from the National Statistical Office (SURS). In each class (see table 2 for class sizes) 40 conventional farms were selected to enable a final sample size of 33 farms per class. The initial survey was performed during the winter 2005 for both groups.

Because of the time difference between database establishment (year 2000 for the purpose of national agricultural census) and realisation of our survey, the selected sample didn't prove to be adequate. There were some farms in the sample that had stopped with farming, or its economic size changed. So additional sampling for conventional farms was necessary and a second round of interviews was done in late summer 2005. Thus, for inferences to the regional farm population, the sample needed to be weighted.

Table 1: Number of farms and their distribution in the region and in the planned sample (Source: SURS 2006; regional data per 31. 12. 2004)

\begin{tabular}{l|l|r|r}
\hline \multicolumn{2}{l|}{} & Region & Sample \\
\hline Conventional farms & Subsistence (<1 ESU) & 801 & 0 \\
& Small (1<2 ESU) & 680 & 33 \\
& Medium (2<6 ESU) & 778 & 33 \\
& Large (6 ESU and more) & 560 & 33 \\
Sub-total & & 2819 & 99 \\
Organic farms* & Subsistence (<1 ESU) & 6 & 0 \\
& 1 ESU and more & 66 & 66 \\
\hline Sub-total & & 72 & 66 \\
\hline
\end{tabular}

* Including farms in conversion; 1 ESU = total standard gross margin on a farm divided by 1200 Euros

Table 2: Distribution of sample farms by economic size classes in realised survey

\begin{tabular}{|c|c|c|c|c|c|}
\hline & \multicolumn{4}{|l|}{ Size classes } & \multirow[b]{2}{*}{ Total } \\
\hline & Subsistence & Small & Medium & Large & \\
\hline Conventional farmers & 15 & 18 & 33 & 32 & 99 \\
\hline Organic farmers & 2 & 5 & 29 & 22 & 58 \\
\hline Total & 17 & 23 & 67 & 49 & 157 \\
\hline
\end{tabular}

The personal interviews were based on fully structured questionnaires that were pre-tested in this, and five further regions in other EU accession countries. The questionnaire consisted of 250 variables grouped in seven sections:

4 ESU - European Size Unit is a measure of the economic size of a farm business based on the gross margin imputed from standard coefficients for each commodity on the farm. The application of these standard coefficients results in the Standard Gross Margin (SGM) for a farm or group of farms (1 ESU $=1200$ EUR). 
- role of formal institutions and information sources,

- general attitudes towards environment,

- conversion to organic agriculture,

- characteristics of the farm,

- characteristics of farm manager and his family,

- finance and market development, and

- specific attitudes - behavioural relationships.

The opinions variables of interviewees were measured on semantic differential scales ranging from 1 to 7 .

In this article we present the results of the analyse of differences between organic and conventional farms in farm size, education, information sources about agricultural production methods, dependency on farm income and personal attitudes towards environmental and economic factors.

The quantitative analysis of the survey data was done by means of descriptive statistical analysis, and research questions were tested by use of chi-square test for two independent variables.

\section{EMPIRICAL RESULTS}

\section{The farm population}

The general characteristics of total farm population as well as organic farms in the survey area compared to the whole country are presented in the tables 3 and 4 . The regional data on organic farms were provided by the organic farmers association of Podravje.

Within the survey we defined as organic farmers those farmers, who already received certificate of organic agriculture, are in the process of conversion, and as conventional farmers are indicated those farmers who are farming in conventional way.

Table 3: Total and organic farm populations in Slovenia. 2000 and survey region (SURS, 2002)

\begin{tabular}{l|r|r}
\hline & Country & Survey area \\
\hline Total no. farms* & 86,427 & 3,078 \\
\hline No. organic farms** & 620 & 78 \\
\% of total no. farms & $1 \%$ & $3 \%$ \\
\hline Total hectares farmed & 537,249 & 15,539 \\
Hectares farmed organically & 5,425 & 903 \\
\% of total hectares farmed & $1 \%$ & $5.8 \%$ \\
\hline Average size of agricultural holdings*(ha) & 6.2 & 5.0 \\
Average size of organic holdings**(ha) & 8.8 & 11.6 \\
\hline Farm types specialist crops & 13,177 & 463 \\
Farm types specialist livestock & 24,312 & 650 \\
Mixed farm types & 48,942 & 1,865 \\
\hline Individual farms & 86,336 & 3,075 \\
Corporate farms & 131 & 3 \\
\hline
\end{tabular}

* Excluding household plots. ${ }^{* *}$ Including farms in conversion. 
Table 4: Size structure of farms in survey area, 2000 (SURS, 2002)

\begin{tabular}{|l|c|}
\hline Number of predominately subsistence farms* & 964 \\
\hline Number of small, but trading farms $(<=5 \mathrm{ha})$ & 1119 \\
\hline Number of medium sized farms & 595 \\
\hline Number of large farms $(>=10 \mathrm{ha})$ & 400 \\
\hline Total & 3078 \\
\hline Total excluding predominately subsistence farms & 2114 \\
\hline
\end{tabular}

* E.g. if a farm sells only a minor part of its products to neighbours, this still counts as being predominately subsistent.

Farms in Slovenia are mostly of mixed type, what is a consequence of natural conditions and big share of absolute grassland. Also in our sample we can found the same situation with $53 \%$ of organic farmers' and $61 \%$ of conventional farmers' farms being of mixed crop-livestock type. The next most frequent farm type among conventional farmers are specialised field crops farms with $13 \%$ and among organic farmers specialised grazing livestock farms (38\%). All the other types are presented with small share of farms.

Full time family farms present $74 \%$ of all organic farmers' farms in a sample and almost $52 \%$ of conventional farmers' farms. Organic farmers are thus more professional engaged in agriculture.

Table 5: Descriptive statistics for the sample

\begin{tabular}{|c|c|c|c|c|}
\hline \multirow[t]{2}{*}{ Variable } & \multicolumn{2}{|c|}{ Organic farmers (58) } & $\begin{array}{l}\text { Conventional } \\
\text { (99) }\end{array}$ & farmers \\
\hline & Mean & SD & Mean & SD \\
\hline Age of farm manager & 48.5 & 11.274 & 54.4 & 12.181 \\
\hline Income earned from farming $(\%)$ & 32.86 & 19.94 & 39.43 & 25.686 \\
\hline Farm size (ha) & 3.71 & 2.209 & 4.53 & 1.72 \\
\hline Predominant farm type & $\begin{array}{l}\text { Mixed crop - } \\
\text { livestock }(53 \%)\end{array}$ & & $\begin{array}{l}\text { Mixed crop - } \\
\text { livestock }(61 \%)\end{array}$ & \\
\hline
\end{tabular}

$\mathrm{SD}=$ Standard Deviation;

Among questioned farm managers most of them were males. Women presented $33 \%$ of questioned organic farmers and $27 \%$ of conventional farmers. $69 \%$ of organic farmers and approximately $48 \%$ of conventional farmers are full-time engaged in farming. The rest are part-time farmers. Regarding the age structure of farmers/managers there are noticeable differences in age structure of farmers between organic farmers and conventional farmers. By the organic farmers the younger age groups show higher share of managers as by conventional farmers and opposite. In last two classes (older than 56 years) we can find almost half $(48.5 \%)$ of conventional farmers and only $25.9 \%$ of organic farmers, what indicates that younger farmers are more interested in adopting organic farming, what is also confirmed by the chi-square test $(p=0.02$ ). More than $86 \%$ of organic farmers and $94 \%$ of conventional farmers have children, so they can expect that their family farming will continue. 
For Slovenian farmers is typical that they gained their farming experiences from onfarm training and different courses organized mostly by Agricultural Advisory Service. The questioned farmers also show this pattern with the highest share of farmers in both samples having only on-farm training with the combination of their own learning (from books and practical experiences) or just on-farm training. Frequent combination is also on-farm training, own learning and some courses. Only $20.7 \%$ of organic farmers and $17.2 \%$ of conventional farmers have an agricultural high school of higher level of agricultural training. The general education of questioned farmers can be, in comparison to results from Agricultural survey data from 2000 (SURS, 2002), valued as good. Organic farmers are having higher level of education as conventional farmers, but the difference is not significant $(p=0.1)$, so it can't be presumed that the level of education influences the decision for conversion. Most of questioned farmers of both groups have secondary education. Bigger difference is regarding farmers with finished college or university. Around $17 \%$ of organic farmers and $8 \%$ of conventional farmers finished college or university.

\subsection{Role of formal institutions and information sources}

Farmers are generally not very often members of different associations and organisations, and when they are members, then this organisations are often of professional nature. In the analysed case the organic farmers are in high share members of organic farming association ( $86.2 \%$ of them), while conventional farmers are mostly members of farming co-operative but with much smaller share $(29.3 \%$ of them). Results also show that organic farmers are more often attending meetings of their organisations as conventional farmers. The highest share of organic farmers attends meetings of Organic farming association and farming co-operative meetings. Conventional farmers attend fewer meetings, mostly of farming co-operatives or other formal or informal farmer groups (mainly Cattle breeders associations and Agricultural and Forestry Chamber).

Farmers get general information on agriculture from different sources. Organic farmers get them mostly from organic farming associations, while the most important source for conventional farmers are farming co-operative and agricultural extension service. For conventional farmers important source of information is also talking with other conventional farmers and Farmers' union.

Most important general information source for organic farmers are Organic farming associations and agricultural advisory service. All the other sources are not so often used. Conventional farmers get general information on agriculture mostly from agricultural advisory service and from other conventional farmers and farming cooperatives. The forth most important information source for conventional farmers are agricultural publications. Modern communication sources are almost not in use in both groups. 


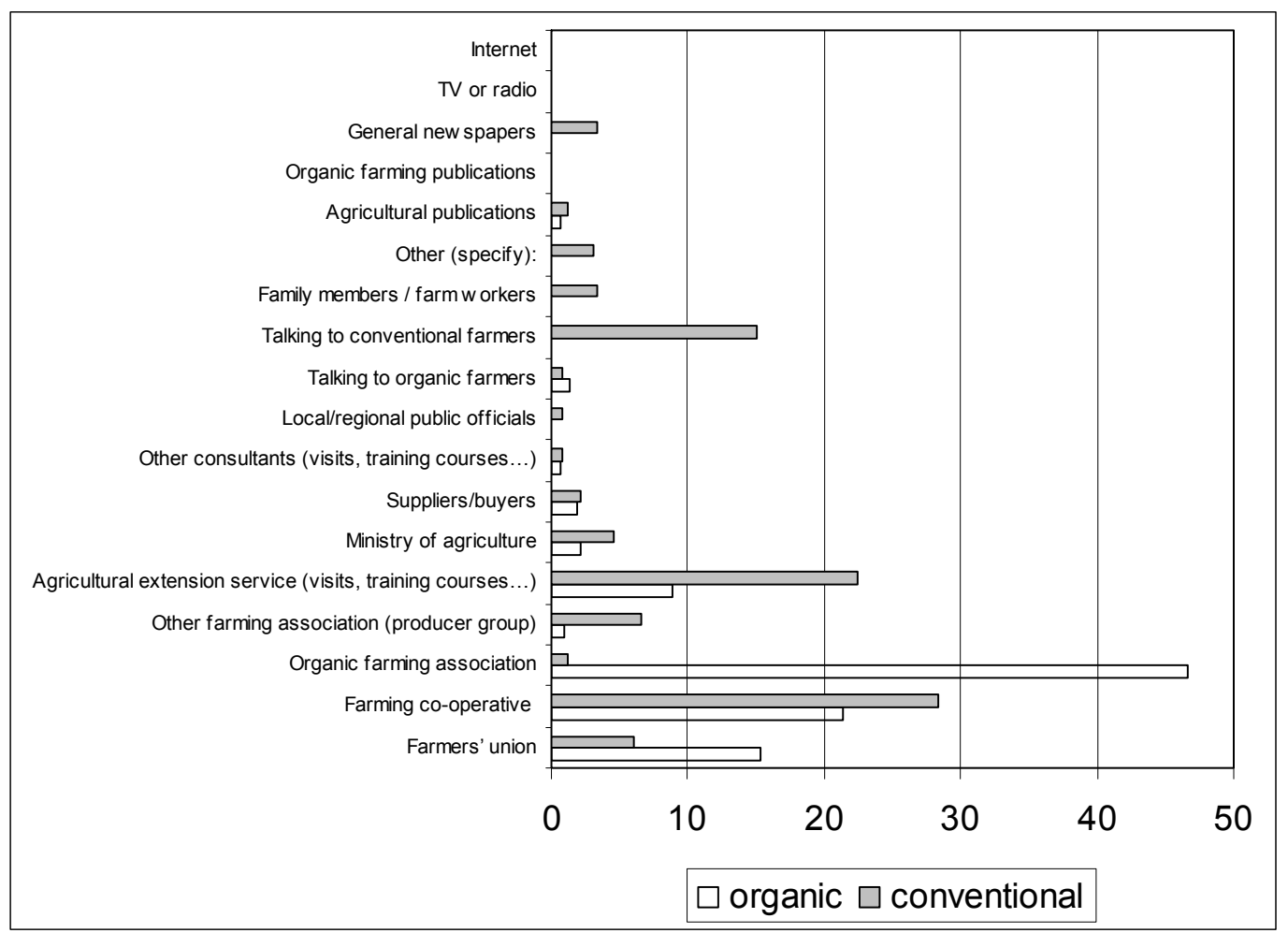

Picture 1: Number of farms which use specified information sources

Both groups of farmers answered also about their main source of information on organic farming. As expected the most important source of information on organic farming for organic farmers are Organic farming associations, less frequent sources are also farmers' union, farming co-operatives and agricultural advisory service. Conventional farmers get information about organic farming mostly from other conventional farmers, from agricultural advisory service and farming co-operatives. It is interesting that both groups of farmers don't use modern information sources as internet and TV or radio. Media source were not very often mentioned. Newspapers and agricultural publications are used more often from conventional farmers as from organic farmers.

Regarding the opinion about organic farming, conventional farmers in general think that majority of farmers have more or less good opinion about it. The organic farmers opinion is less optimistic and there is a significant difference among both groups $(\mathrm{p}=0.001)$.

\subsection{Successor situation}

Assured successor is one of the important factors for long term family farming sustainability. Successor is already known on $39.7 \%$ of organic farmer's farms and on $40.4 \%$ of conventional farmer's farms and successor status has not significance for adopting the organic farming. More than $20 \%$ of organic farmer's and conventional farmer's farms don't have assured successor and on the rest of farms it is not applicable because of different reasons: children are still too young, farm is owned by parents, farm is small, farmer's wife is against potential successor, farmer is not owner of the farm and farm is already on sale. 
On the question how successor situation influences on the decision weather to convert to organic farming or not the answers among organic farmers group were bit surprising, because big share of them answered that successor situation is not important at all for their decision. So the decision to convert is not much connected with future but with present situation and with present generation. Only smaller share of organic farmers put bigger importance of the successor situation in decision process. Conventional farmers predominantly consider successor situation as quite, slightly or even very important, but smaller part of them also as not important factor. The answers between the groups are significantly different $(p=0.001)$.

\subsection{Farmers attitude towards environmental and economic factors}

In general both groups are showing positive concern about their environment, but some differences in attitudes between organic farmers and conventional farmers are noticeable. Organic farmers concern significantly more $(p=0.001)$ about most mentioned environmental problems as shows in the picture 2. Only in case of personal health and own personality (Me) the differences are not significant. The highest concern is in both groups given for their children and future generations. Organic farmers showed the lowest concern for other people in community, while conventional farmers have the smallest concern for marine life. The same situation is noticeable in their relationship with the natural environment. Both groups of farmers feel closely connected with a nature. The reason for this can be explained as the agricultural activities are very connected with nature and also depend on nature and natural conditions. Also here organic farmers are more narrowly connected with nature as a conventional farmers (average score $2.84: 2.54$ ).

Organic farmers and conventional farmers have in most cases from $25 \%$ to $50 \%$ of their farm's annual gross income from farming. In average conventional farmers have $39 \%$ of income from farming and organic farmers $32.9 \%$ (see table 5). The share of income from farming is not significant for decision to adopt organic farming.

Picture 3 present average distribution of different kind of incomes on interviewed farms. Comparing average amounts we can see that income from farming is more important for conventional farmers (but not significant), on farm activities bring significantly $(\mathrm{p}=0.001)$ more income on organic farmer's farms, off-farm activities contribute also to farm's annual gross income (more important for conventional farmers, but not significant), while subsidies present bigger part of farm income for organic farmers $(p=0.01)$ as for conventional farmers. The reason can be found in fact that organic farmers get money also to implement other measures of Slovene AgriEnvironment Programme (SAEP). Unearned income (i.e. social transfers) in average is also important for overall farm income $(18.2 \%$ of total farm income for organic farmers and $26 \%$ for conventional farmers). 


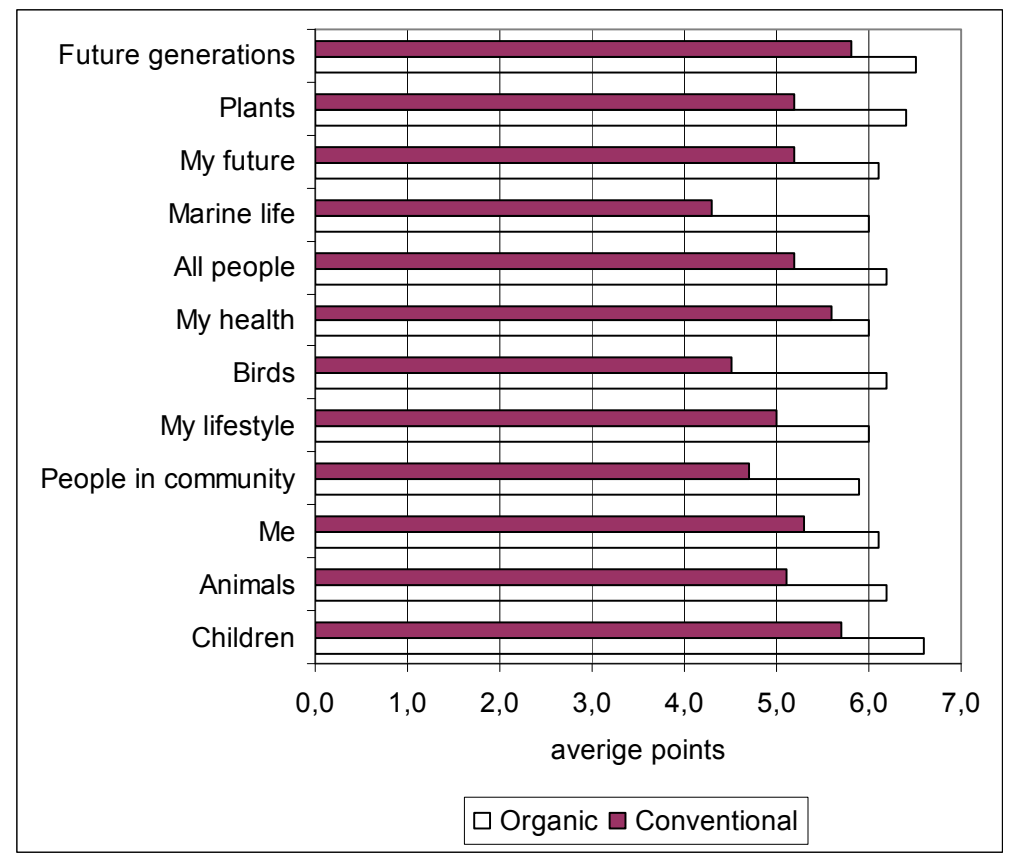

Picture 2: Average scores for different concerns regarding the environment

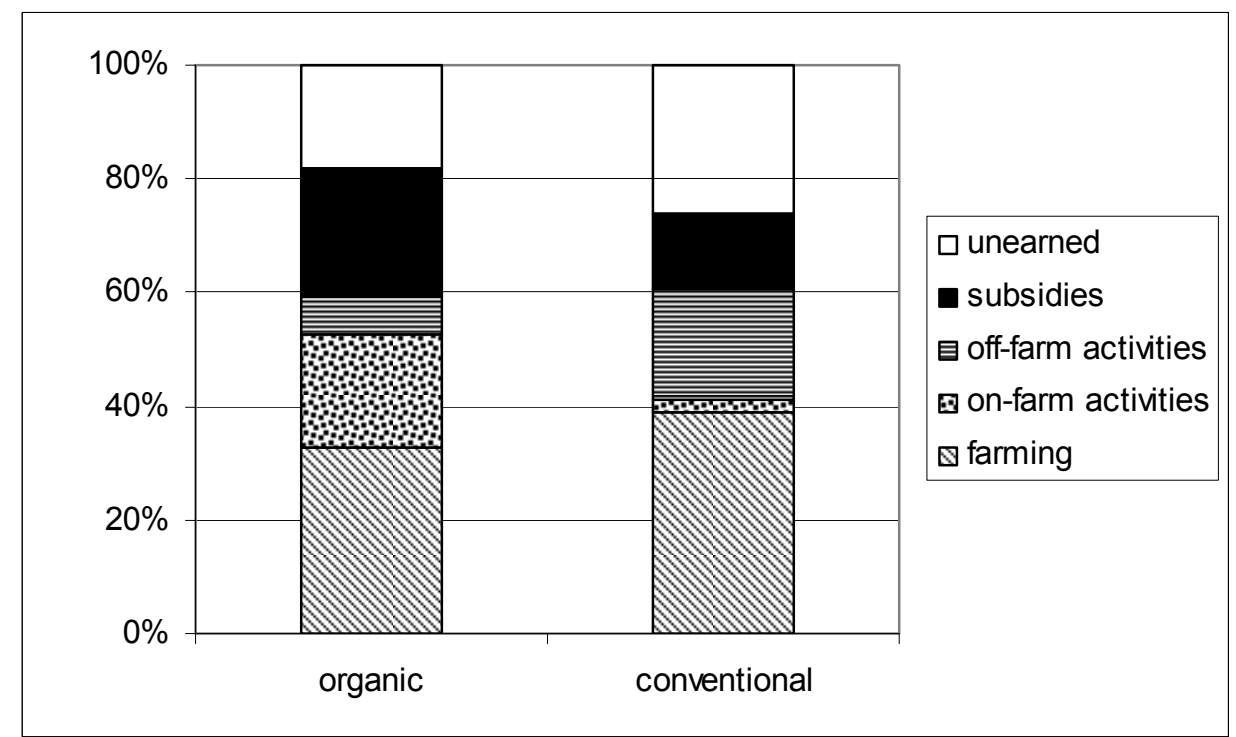

Picture 3: Average income structure on organic farmers' and conventional farmers' farms

Analysis of farmers' attitude towards environmental and economic factors of their business operations showed certain difference between organic farmers and conventional farmers. The organic farmers are assessing the listed environmental and economic factors higher then conventional farmers with the exception of profit maximisation. The statistically significant difference could be calculated by possibility for providing on farm employment and opportunity to expand the business. 


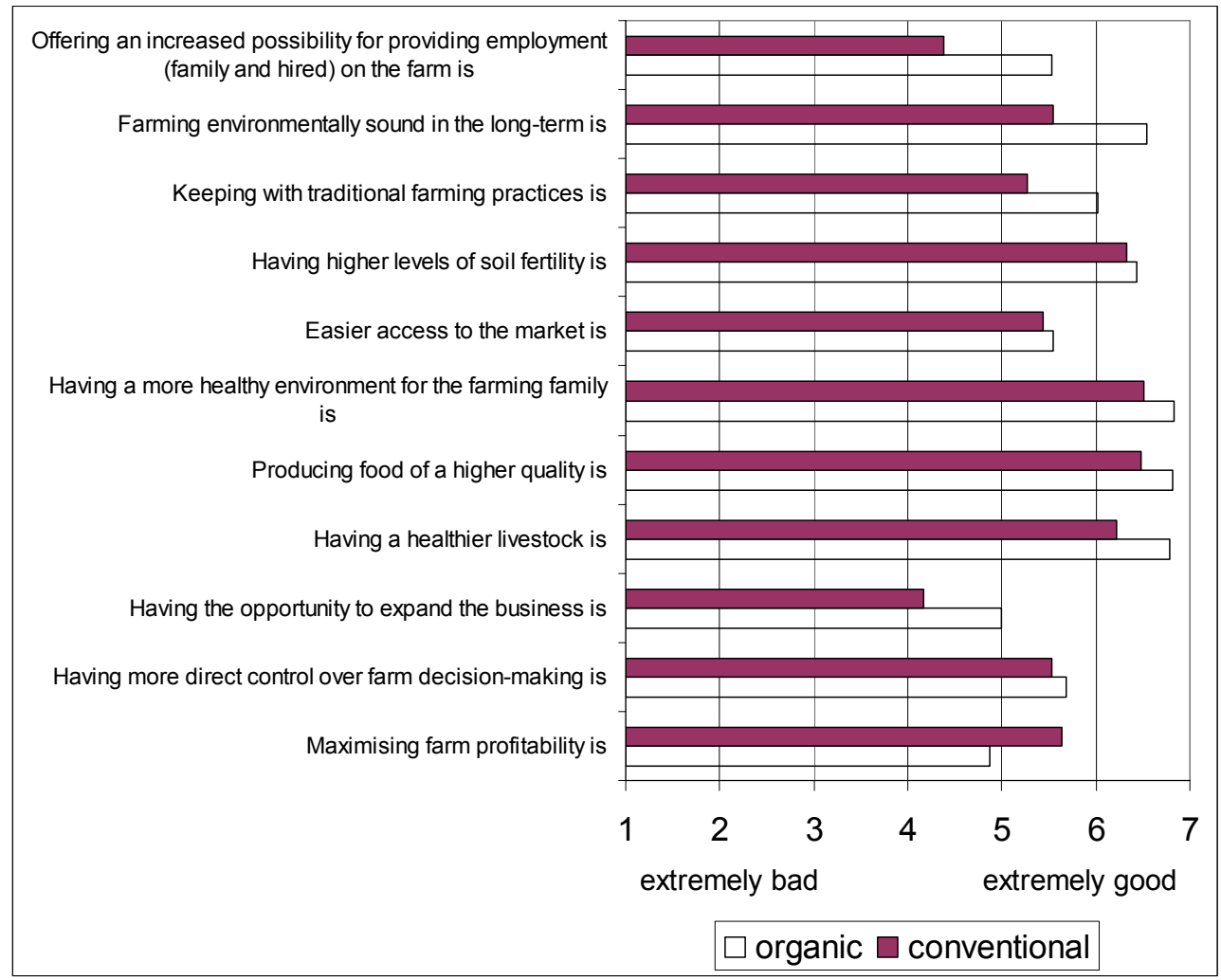

Picture 4: Scores for personal importance of certain factors for farm managers

The results of the analysis also show that conventional farmers mostly do not plane to convert within the next 10 years or are not really certain about that option (score 4) (Picture 5). But on the other hand 50\% of them stated that they will monitor the development within the organic production and they leave open the possibility to reconsider it.

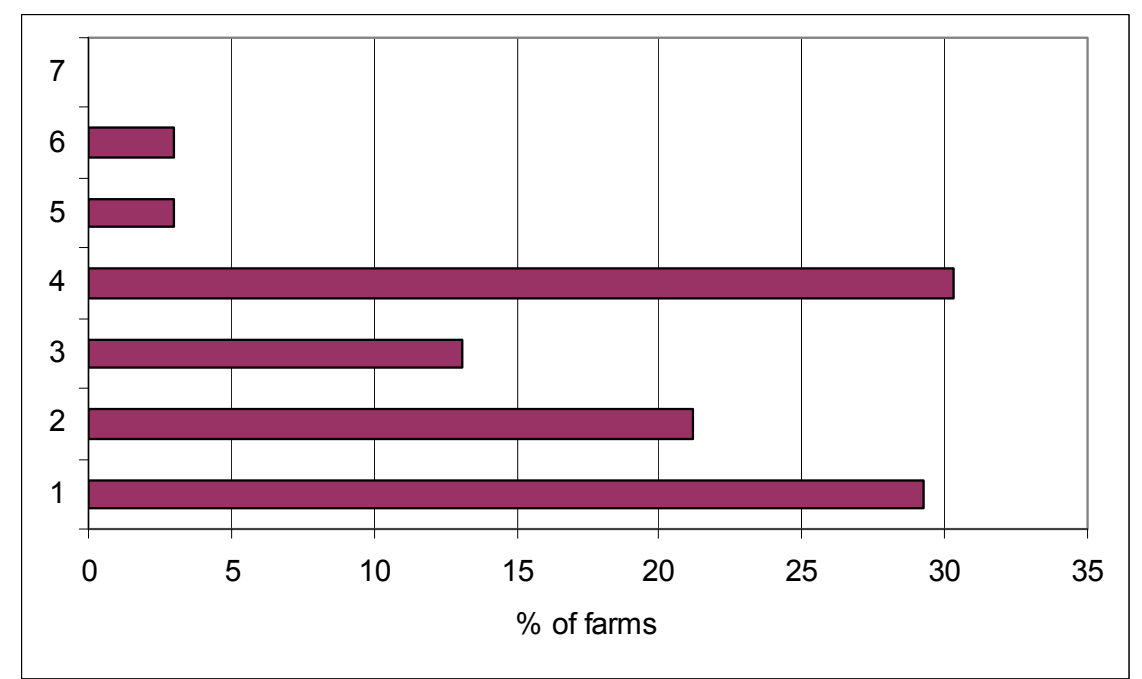

Picture 5: Likelihood of conventional farmers to convert in next 10 years (1- strongly disagree, 7 - strongly agree)

Also the results on a question "What is the likelihood of you having a farm appraisal for investigating 'organic farming' as a possible alternative to conventional farming over the next 10 years?" show that $40 \%$ of conventional farmers consider it likely to 
extremely likely. For all the other this is unlikely to extremely unlikely. This shows that there is a certain insecurity about the future development of conventional agriculture for small Slovene farms. And as official agricultural policy is for the future strongly promoting the stronger shift towards more sustainable and organic agricultural production the farmers do consider this option also in their future development alternatives.

\section{CONCLUSIONS}

Comparing the results to previously published analysis (Wilson, 1997, Diederon, 2002, Burton 1999 and 2003, McCann and Sullivan, 1997) we can see that our results in general confirm our hypothesis and previous findings that there are factors which distinguish organic from conventional farms as farm size, income structure, education, membership of professional associations, dependency on farm for income and personal attitudes towards environmental concerns, but some of them did not proved to be statistically significant (education, share of income from agriculture).

On the other side the successor factor proved to be more important to conventional farmers as to organic farmer what contradicts to what was stated by research of Wilson (1997), Potter and Lobley (cit. by Wilson, 1997). This result can be partly explained with the fact that for one half of questioned farmers the successor question is not an issue, as the farmers are still young or they already have the successor. Though there is no significant difference in the successor situation structure the difference in importance of successor factor my rise from the fact that smaller conventional farmer generally feel higher level of insecurity regarding their farm future, mostly because the next generation has better income opportunities in off farm activities.

Though, investigating the motivational and financial structures of organic farmers lets us conclude that adopters could partly not realise their expectations or they decided for organic production as this enabled them to get some extra income from subsidies not forcing them to significantly change their production techniques. They have mostly been producers of milk and cattle, which can often not earn an extra margin on the organic market, pointing towards a mismatch of supply and demand not only in quantity, but also in the kinds of products as the demand for organic products still exceeds what is offered in many product categories (Akcijski načrt..., 2005).

Considering this and the results of the presented survey we can anticipate, that the future adoption of the organic agriculture is dependant on one side on the future development of the demand for organic food products and its processing possibilities (most important segment are animal products), and on the other side the future development of economics of conventional and organic agriculture especially for small size part time farms which are typical for Slovenia and are at the moment still continuing with its low intensity conventional production. 


\section{REFERENCES}

2005. Akcijski načrt razvoja ekološkega kmetijstva v Sloveniji do leta $2015=$ Action plan for development of organic Agriculture in Slovenia till the year 2015. Ministry of Agriculture, Forest and Food of RS http://www.mkgp.gov.si/ si/novinarsko_sredisce/novica/browse/8/article/946/2173/?cHash=ded0685694 (5.9.2006)

2006. Strategija razvoja podeželja 2007-2013 = Rural development strategy 2007 - 2013. Ministry of Agriculture, Forest and Food of RS http://www.mkgp.gov.si/ fileadmin/mkgp.gov.si/pageuploads/saSSo/PRP_2007-2013/PRP30maj/prp3105/ PRP19jun07PROGRAM_RAZVOJA_PODE.pdf (19.6.2007)

Burton, M., D. Rigby and T.Young, 1999. Analysis of the Determinants of Adoption of Organic Horticultural Techniques in the UK. Journal of Agricultural Economics, 50(1): 47-63.

Burton, M., D. Rigby and T.Young 2003. Modelling the adoption of organic horticultural technology in the UK using Duration Analysis. The Australian Journal of Agricultural and Resource Economics, 47:1, pp. 29-54

Chaves, B. Riley, J. 2001. Determination of factors influencing integrated pest management adoption in coffee berry borer in Colombian farms. Agriculture, Ecosystems and Environment 87 (2001) 159-177

Diederen, P. van Meijl, H. Wolters, A. 2003. Modernisation in agriculture: what makes a farmer adopt an innovation? International Journal of Agricultural Resources, Governance and Ecology, 2(3-4) 328-342

Jelen P. 2003. Analiza mnenja prebivalcev Koroške o ekološki pridelavi hrane = Opinion analysis about ekological produced food among resident from Koroška Biotehniška fakulteta, Oddelek za agronomijo, Ljubljana.

Kejžar T. 2003. Analiza mnenja prebivalcev Zgornjesavske doline o ekološko pridelanih živilih = Opinion research survey on organic food in Upper Sava Valley Biotehniška fakulteta, Oddelek za agronomijo, Ljubljana.

McCann, E. Sullivan, S. 1997. Environmental Awareness, Economic Orientation, and Farming Practices: A Comparison of Organic and Conventional Farmers. Environmental Management Vol. 21, No. 5, pp. 747-758

Serjun T. 2005. Analiza mnenja prebivalcev Ljubljane o ekološko pridelanih živalih $=$ Analysis of the opinion of the residents of Ljubljana on organic food. Biotehniška fakulteta, Oddelek za agronomijo, Ljubljana.

Statistical Office of Republic of Slovenia (SURS). 2002 Agricultural census, Slovenia 2000. http://www.stat.si/pub_rr777-02.asp

Statistical Office of Republic of Slovenia (SURS). 2006. Regional data per 31.12.2004. http://www.stat.si/pxweb/Database/Kmetijstvo/Kmetijstvo.asp

Statistical Office of Republic of Slovenia (SURS). 2006a, Slovene regions in numbers. $\mathrm{http} / / / \mathrm{www}$. stat.si/doc/pub/slovenske_regije_2006-koncna.pdf (15.6.2006)

Stropnik B. 2003. Analiza mnenja prebivalcev Savinjske doline o ekološko pridelanih živilih $=$ The analysis of opinions about organic farming production among the population of Savinjska valley Biotehniška fakulteta, Oddelek za zootehniko, Ljubljana.

Škerbot I., Uranjek B. 2005. Rezultati kontrole in certifikacije ekološkega kmetijstva v letu 2004 pri KGZ Maribor. Biodar, 1: 20-22. 
UDOVČ; A., PERPAR, A.: The characteristics of conventional and organic farmers ..

Ulamec P., Vadnal K., Zadnik Stirn L. 2005. Distribution channels for organic produced agricultural products. The 8th International Symposium on Operational Research in Slovenia, Nova Gorica, Slovenia, September 28-30, 2005. - Ljubljana: Slovenian Society Informatika (SDI), Section for Operational Research (SOR), p. 185-190.

Wilson G. A. 1997. Influencing Farmer Participation in the Environmentally Sensitive Areas Scheme, Journal of Environmental Management, 50: 67-93 